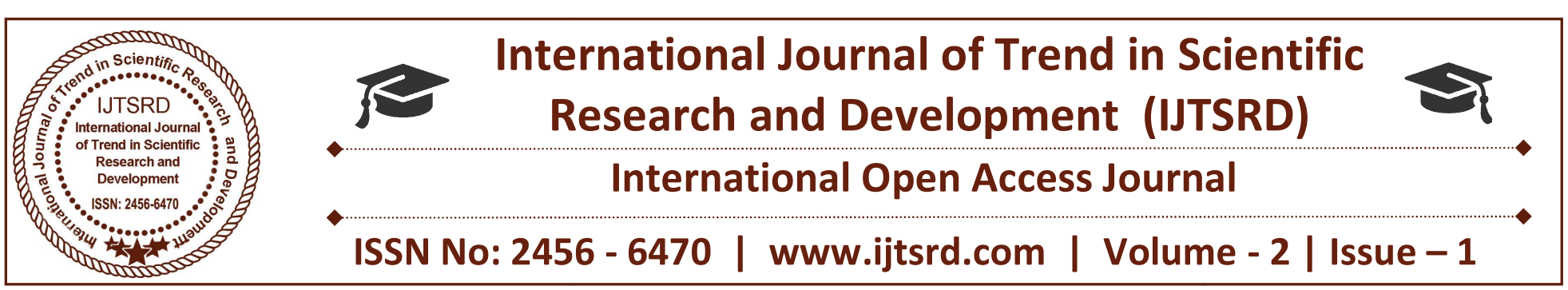

\title{
The Effect of Work Relations on Commitment to Change-A study on small companies in the Pune Area
}

\author{
Dr. Natashaa Kaul \\ Assistant Professor, Indira School of Business \\ Studies, Pune, Maharastra
}

\author{
Prof. Amruta Deshpande \\ Assistant Professor, Indira School of Business \\ Studies, Pune, Maharastra
}

\section{ABSTRACT}

Research has shown that when managers are unable to get employees' commitment to a new Leader-member exchange, commitment to change, dyadic influences idea the implementation of the change fails. In an extension to the work by Jones (2007), this study attempts to understand the role of dyadic influences on gaining employee commitment. The purpose of this paper is to understand the roles that work relations i.e. relationship with the manager and relationship with coworkers play in the employees' commitment to change. The leader-member exchange (LMX) theory is used to understand the dynamics of the relationship between the manager and the employee. The LMX theory and the change management are integrated to understand the interaction between the two. To understand the impact the co-workers have, their opinion on the change as well as the influence of quality of the relationship with the co-worker was measured. Commitment to change was divided into: affective, continuance, and normative commitment to change. Responses were collected from 150 respondents who has recently experienced significant changes in their workplace. The results have shown that the employees' relationship with the manager has a significant influence on the affective and normative commitment to change but not on the normative commitment of the employees. On the other hand, the quality of the relation with the co-worker and commitment to change are positively related and when the relationship is good the opinion of the co-worker is related to commitment to change. Thus, this paper shows the importance of relationships in the workplace on gaining employee commitment to change.
Keywords: Leader-member exchange, commitment to change, dyadic influences

\section{Introduction:}

This need to change can exert a lot of pressure on organizations as well as their employees (Elias, 2009) because these changes can affect the success of the organizations. But these changes are complex and often lead to more problems instead of solving old problems and also do not translate into any improvements. One of the most common reasons for the failure of change initiatives is resistance to change (Oreg, 2006). Resistance to change is to be expected even when the change is very small. Understanding the reasons for this resistance is central to reducing resistance and negative reactions to change and also to reducing the failure rate of change. This is the reason why change and change management is a prominent research theme is social sciences (Cummings \& Worley, 2014; Thompson, 2011).

A popular area of research in change management is on the topic of work relations (Van Dam, Oreg\&Schyns, 2008; Oreg, 2006). There are basically two type of work relationships - those with the manager and those with colleagues. Together these can contribute to the implementation and execution success of organizational change (cf. Van Dam et al., 2008). Research in this area has looked at the context of the psychological processes experienced by employees during organizational changes. Also the role of work relations in terms of the impact on positive individual and organizational outcomes for change initiatives are studied (Dutton 
\&Ragins, 2007). Researchers (Bommer et al., 2005; Bass, Avolio, Jung \&Berson, 2003) have also explored the positive impact that leadership style can have on positive work outcomes with reference to organizational change. In this area of leadership the studies have focused on how the leader handles, implements and leads change but there is limited attention paid to the effect that the quality of the relationship between the employee and the leader during the change process or on how the quality of the relationship can influence the attitude of employees towards the change initiative since they yield influence on the employee. The argument is that when the employees have a high quality relationship with their leader they would have an influence on employee commitment to the organization as well as to the change initiative. Even in cases where leadership quality has been studied only higher hierarchy levels are chosen and there are no studies on the lower management levels. It would be interesting to understand influence at the lower level. After leadership another important work relationship is that with colleagues. There is very little research in this area. Prominent work in this area is done by Madsen et al. (2005) who reported that "employees' feelings, attitudes, and perceptions (positive or negative) toward workplace colleagues (supervisors, subordinates, and peers) with whom they work directly or indirectly are significantly related to the attitude toward change and organizational culture" (p. 228). Previously also Burkhardt (1994) showed that there is signification relationship between the attitude of an individual towards change and the attitude of others in their communication network. So there is some literature available that shows that there is a significant relationship between employee attitudes and peer attitudes but there is a gap in research in terms of the relationship between the relationship quality with peers and the influence of this relationship on commitment to change.

A gap remains in the understanding of employee commitment to change and relationship quality with the leader. This study discusses the effect of workrelationships, studied from an employee's perspective. The aim of this study is to understand if the work relationships and change management are related. The research question of the study is - to what extent do work-relationships influence the employee's commitment to change.

This study makes a contribution to literature in the areas of change management, leader member exchange theory and commitment to change by studying the impact of variables on commitment to change. The work context and the daily work routine of the employees can have an impact on the way the employees perceive the change and also on how it is implemented and so this affords the study a subtle variation to understand the impact of work relations on commitment to change.

\section{Literature Review:}

Conner (1992) has described commitment to change as "the glue that provides the vital bond between people and change goals" (p. 147). On the other hand Lau and Woodman (1995) described change as a specific attitude that employees have towards change. In this paper, the definition of Herscovitch and Meyer (2002) is taken. They have defined commitment to change as "a mind-set that binds an individual to a course of action deemed necessary for the successful implementation of a change initiative".

Herscovitch and Meyer (2002) also pointed out that people have a number of different motivations to change- some are committed to the change because they love their jobs, some because the individual and organizational goals are aligned and some others because they are afraid to lose their jobs. This is aligned with the three component model of attitude given by Meyer \& Allen (1991). Their model explained affective commitment, continuance commitment, and normative commitment as components of commitment (Meyer \& Allen, 1991) and this model has since been extrapolated to understand different forms and types of commitment (Herscovitch and Meyer, 2002).

Based on extrapolating this model to understanding the commitment to change, the three components of change are as follows. Affective commitment to changedescribed as a desire to support change based on the fact that it has inherent benefits. Continuance commitment to change described as understanding that there are costs associated with failure to change. Normative commitment to change is described as the sense of obligation that employees experience to support the change. In this paper these three components are used as indicators of the degree of commitment to change. There has been research on the effect of contextual factors on the degree of commitment to change (Benn, Dunphy, \& Griffiths, 2014; Cumings\& Higgins, 2006). In this study variables related to work relations with the manager as well as with co-workers are considered. These relationships are explained in detail below. 


\subsection{Work relations with the manager:}

One area of focus in this study is the influence that the relationship between the manager and the employee has on commitment to change. Managers play an important role on the organizational life of the employee (Kram\& Higgins, 2009). Especially during organizational change processes, the managers are involved in managing the different stakeholders, coordinating the change process, aligning strategy with operations and developing reward structures (Kram\& Higgins, 2009). It is the manager who takes on the role of the leader and shares the vision of the change with the employees, encourages them to evaluate the change and gives them confidence in adapting to the change (Bass et al., 2003). Managers can gain support for the change processes by leading the change themselves (Moran \& Brightman, 2000).

During organizational change, individuals need and get support from their organizational relationships like colleagues, subordinates, managers, etc. (Ford et al., 2003). Martin and Epitropaki (2005) have shown that leadership traits can indirectly influence the attitude and behavior of employees. And managerial support during change is very important especially with reference to reaction to change (Amiot et al., 2006). Oreg (2006) also found that managerial support influences resistance to change. Logan and Ganster (2007) also reported that when employees have managerial support during a change they have less negative reactions and show higher readiness to change.

Leader-member exchange (LMX) focuses on the understanding leadership as a relationship between a leader and follower (Uhl-Bien, Graen\&Scandura, 2000). The theory states that leaders (or supervisors) have differential relations with their followers (or subordinates). Research (e.g. Cogliser et al., 2009; Bauer, Erdogan, Liden, \& Wayne, 2006) has established that LMX is related to outcomes like performance, job satisfaction, and organizational commitment. LMX literature has shown that when the quality of the relationship with the leader is high the employee displays more positive attitudes and behaviors (Sherony\& Green, 2002). Hofmann et al., (2003) have showed that when quality of relation with the leader is high the employee's cooperation with change or the willingness to change is high.

Also when quality of relations is high, the employee and the manager (leader) have more frequent communication and so the employees trust the managers more and the managers show greater support
(Dulac et al., 2008). Also the high frequency of communication affords more opportunity to explain the circumstances of change. Also in high quality relations employees have high commitment to the supervisor and as willing to do more (Cropanzano\& Mitchell, 2005). Not just this, those is high quality relations also have a greater understanding of the broader picture and thus feel more informed (Uhl-Bien et al., 2000).

Based on this line of thinking the study proposed that the quality of the relationship with the manager will influence employees' commitment to change. Such that when quality of relations is high the commitment to change will be higher and vice versa. So the following hypothesis is proposed:

Hypothesis 1: The quality of the relationship with the manager is positively related with employees' commitment to change.

Also it would be interesting to explore how the attitude of the manager to the change influences the attitude of the employee. It could be expected that when the managers have a positive attitude to the change the employees are also more likely to view the change positively. And thus, how the employee's perceive the manager's attitude to change can also influence the commitment to change, such that those in high relations will show higher commitment to change when they have the perception that the manager is positive about the change. So the following hypothesis is proposed:

Hypothesis 2:Employees' perceptions of manager's opinion about the change and perceived quality of a manager relationship interact such that when the employees perceive the manager's attitude to change as positive they will show higher commitment to change than if they had the same perception and were in a low quality relation.

\subsection{Work relations with colleagues}

There has been some research on the effect of relationship with the leader on employee attitudes and behavior but there is very little work in the area of influence of other work relationships. Research gas overlooked the relations at lower hierarchical levels (e.g., work teams) where the employees need to show compliance as per group norms or other pressures (Hill et al., 2012). So an important factor of the group as a source of social influence is overlooked and the dynamics of the work unit ignored.

Similar to the LMX logic, the nature of relations with the team members can also shape daily behaviours 
since both relations share similar attributes (Liden et al., 2000). Two decades back Burkhardt (1994) showed that there was a significant relationship between an individuals' attitudes and behaviour about change and the attitudes of others in their communication network.Jones and George (1998) also showed that high relationship quality with team peers leads to an expansion of bounders, more involvement and a subordination to group needs. Also they pointed out that more information is shared in teams where members share high quality relations. Liden et al., (2000) also found that when information is freely exchange, team relations are of a higher quality. Eby et al. (2000) also reported that trust in peers is related to positive work outcomes.

Madsen et al. (2005) reported that "employees' feelings, attitudes, and perceptions toward workplace colleagues (e.g. supervisors, subordinates, and peers) are directly or indirectly significantly related to the attitude toward change and organizational culture" ( $p$. 228). Earlier Woodward et al. (1999) had stated when employees have supportive peers they are able to better cope with the stress of change. Similar findings have also been reported by Shaw et al., (2006) and Cunningham et al. (2002). Thus peers can influence commitment to change by changing attitude or helping to cope with change. In light of this positive influence it can be expected that positive relations with colleagues will positively influence employee commitment to change.

Hypothesis 3: The quality of the relationship with colleagues is positively related with employees' commitment to change.

Also the aim is to understand the extent of the influence. So it can be expected that in the case when the relations with colleagues are high and they hold a positive view on change the attitude of the employee will also be positive. Thus the following hypothesis is proposed:
Hypothesis 4: The employee's perception of the view of the colleagues of change and the perceived quality of colleagues' relationship interact such that employees who believe their colleagues have a positive attitude towards the change will report stronger commitment to change when they have a high quality relationship with their colleagues than when they have a low quality relationship with their colleagues.

\section{Methodology:}

Data was collected from employees in organizations that has experienced significant change in the last 2-3 months. In most cases the change was organizational restructuring. Respondents were contacted and requested to fill the survey online. A brief introduction to the study was given and in order to prevent socially desirable answers, the real purpose of the study was not disclosed initially. They were assured that participation is voluntary and answers anonymous.

\subsection{Measurements:}

Work-relationship with managers. Employees' perceptions of the quality relationship with the supervisor were measured using the seven-item LMX (LMX-7) instrument (Uhl-Bien et al., 2000) on a 5 point Likert scale. A sample item was 'My supervisor understands my problems and needs well enough'. The Cronbach's alpha for the items is $\alpha=0.91$.

Work-relationship with colleagues. The quality of relationships with colleagues was measured using as adaptation of TMX instrument used by Seers et al. (1995). This measured the employees' view of the quality of working relationships with other team members. Level of agreement was measured on a 5 point Likert scale. The Cronbach's alpha for the items is $\alpha=0.77$. 


\section{Results \& Discussion:}

Descriptive statistics are in the table below.

Table 1: Descriptive statistics, and Cronbach's alpha for all variables.

\begin{tabular}{|l|l|l|l|l|l|}
\hline Variable & M & \multicolumn{1}{l}{ SD } & \multicolumn{2}{l|}{ No. of items } \\
\hline Dependent Variables & 3.84 & 0.63 & 0.85 & 6 \\
\hline Affective Commitment & 3.11 & 0.67 & 0.69 & 5 \\
\hline Normative commitment & 2.98 & 0.86 & 0.8 & 6 \\
\hline Continuance commitment & & & & \\
\hline
\end{tabular}

Note. Means (M's), standard deviations (SD's), and Cronbach's alpha $(\alpha)$ are reported for 150 respondents on a 5point scale

Multiple regression was used to examine the relationship between the different variables. In this case multiple regression has been used to study the effect- positive or negative on an independent variable on the dependent variable. Commitment to change was the dependent variable and quality of relations was the independent variable. From running a multiple regression we found out how much variance in the dependent variable is explained by the model. As seen in the table below for affective commitment the value of $\mathrm{R}$ Square is $\mathrm{R}^{2}=.48$. for continuance commitment $\mathrm{R}^{2}=.37$ and for normative commitment $\mathrm{R}^{2}=.32$.

\section{Table 2: Correlation matrix}

\begin{tabular}{|c|c|c|c|c|c|c|c|c|}
\hline & & $\mathbf{A}$ & $\mathbf{B}$ & $\mathbf{C}$ & $\mathbf{D}$ & $\mathbf{E}$ & $\mathbf{F}$ & G \\
\hline A & Affective commitment & - & & & & & & \\
\hline B & $\begin{array}{l}\text { Continuance } \\
\text { commitment }\end{array}$ & $-.32 * *$ & - & & & & & \\
\hline $\mathrm{C}$ & $\begin{array}{l}\text { Normative } \\
\text { commitment }\end{array}$ & $0.12 *$ & $0.59 * *$ & - & & & & \\
\hline $\mathrm{D}$ & $\begin{array}{l}\text { Relationship with } \\
\text { manager }\end{array}$ & $0.38 * *$ & $-.18 *$ & 0.15 & - & & & \\
\hline $\mathrm{E}$ & Opinion of manager & $0.41 * *$ & $-.22 *$ & .12 & $0.52 * *$ & - & & \\
\hline $\mathrm{F}$ & $\begin{array}{l}\text { Relationship with } \\
\text { colleague }\end{array}$ & $0.23 *$ & -.8 & 0.6 & -.8 & 0.18 & - & \\
\hline G & Opinion of colleague & $0.32 * *$ & $-.45 * *$ & $-.21 *$ & $0.47 * *$ & $0.38 * *$ & $0.49 * *$ & - \\
\hline
\end{tabular}

Correlation is significant at the 0.01 level $(\mathrm{p}<0.01)$. ${ }^{*}$ Correlation is significant at the 0.05 level $(\mathrm{p}<0.05)$. 
Table 3: Summary of regression analysis for all variable $(n=150)$

\begin{tabular}{|c|c|c|c|c|c|c|c|c|c|c|c|c|c|c|c|}
\hline & B & $\mathbf{T}$ & Sig. & $\Delta R^{2}$ & $\begin{array}{l}\text { Sig } \\
\Delta \mathbf{R}^{2}\end{array}$ & B & $\mathbf{T}$ & Sig. & $\Delta R^{2}$ & $\begin{array}{l}\text { Sig } \\
\Delta \mathbf{R}^{2}\end{array}$ & B & $\mathbf{T}$ & Sig. & $\Delta R^{2}$ & $\begin{array}{l}\text { Sig } \\
\Delta \mathbf{R}^{2}\end{array}$ \\
\hline & & & & 0.07 & 0 & & & & 0.02 & 0 & & & & 0.13 & $\mathbf{0}$ \\
\hline $\begin{array}{l}\text { Relation } \\
\text { with } \\
\text { manager }\end{array}$ & 0.59 & 2.22 & 0.02 & & & 0 & 0.18 & 0.61 & & & 0.79 & 2.62 & 0.01 & & \\
\hline $\begin{array}{l}\text { Opinion } \\
\text { of } \\
\text { manager }\end{array}$ & 0.71 & 2.39 & 0.02 & & & 0.15 & 0.46 & 0.65 & & & 0.91 & 2.74 & 0.01 & & \\
\hline $\begin{array}{l}\text { Relation } \\
\text { with } \\
\text { colleague }\end{array}$ & 0.08 & 0.3 & 0.77 & & & 0.04 & 0.13 & 0.89 & & & -0.7 & -2.06 & 0.04 & & \\
\hline $\begin{array}{l}\text { Opinion } \\
\text { of } \\
\text { colleague }\end{array}$ & -0.42 & -0.59 & 0.56 & & & -0.29 & -0.38 & 0.71 & & & -2.3 & -2.89 & 0.01 & & \\
\hline $\begin{array}{l}\text { Rel } \mathrm{X} \\
\text { opinion } \\
\text { of } \\
\text { Manager }\end{array}$ & -0.8 & -1.72 & 0.08 & & & -0.15 & -0.29 & 0.77 & & & -1.2 & -2.25 & 0.03 & & \\
\hline $\begin{array}{l}\text { Rel } x \\
\text { opinion } \\
\text { of } \\
\text { colleague } \\
\mathrm{S}\end{array}$ & 0.2 & 0.23 & 0.82 & & & 0.09 & 0.1 & 0.92 & & & 2.53 & 206 & 0.01 & & \\
\hline
\end{tabular}

\section{Work-relationships}

A correlation analysis was used to study the impact of a high quality relationship with the manager on affective, continuance-, and normative commitment to change. There was a small significant positive correlation for affective commitment $(\mathrm{r}=.38, \mathrm{p}<, 05)$ normative commitment $(\mathrm{r}=0.15, \mathrm{p}<.05)$. Results from the regression analysis show that relationship with the manager affects affective and continuance commitment so hypothesis 8 is partly accepted.

Also in case of hypothesis 2 the interaction effect comes into play in case of normative commitment to change i.e. employees in high quality relations have more normative commitment to change.

The descriptive statistics show that the respondents in the study are collegial and feel positive about their colleagues. Also there is a correlation between normative commitment to change and relations with colleagues but same results are not found for other forms of commitment. So the influence of colleagues is not high. Hypothesis 4 stated that the perceptions of colleagues' opinion about the change and the perceived quality of the relationship with them interact in such a way that when employees perceive a high quality relation and when they believe that their colleagues have a positive attitude to change they report higher commitment to change. The regression results show that this is the best predictor of normative commitment. Thus, the study suggests that when colleagues share a high quality relationship, the perception of the colleagues' opinion is very crucial to the employees. So hypothesis 4 can be accepted for normative commitment.

Thus, this study points out that work relations do have an influence on commitment to change but the results are not exclusive. Similar results have also been reported by Foks (2015) but the results are largely not supported by literature. The results have pointed out that a high quality relationship with the manager affects only normative commitment to change. The results can be understood in the context of the paternalistic culture of the country where supervisors hold some sway over the subordinates. Also the social exchange theory can used to understand that in organizations which value loyalty, normative commitment is likely to be higher (Higgins \& Thomas, 2001). Even in case of influence 
of colleagues, only normative commitment to change is affected. Normative commitment stems when employees identify with the goals of the organization and hence prefer to remain members of the organization. Relationships with colleagues could shape day to day experiences at work and thus influence normative commitment.

\section{Limitations and Future Research:}

All the respondents experienced differ types of change and the responses could be different for all the different types of change. Future research could explore these differences. Also cross sectional data is collected to causality cannot be established. Impact of other variables on commitment to change can also be explored.

\section{Conclusion:}

This study has shown that work relations do have an influence on commitment to change though the results are not exclusive. Results have shown that work relations primarily affect normative commitment to change.

\section{REFERENCES:}

1. Amiot, C. E., Terry, D. J., Jimmieson, N. L., \& Callan, V. J. (2006). A longitudinal investigation of coping processes during a merger: Implications for job satisfaction and organizational identification. Journal of Management, 32, 552-574.

2. Bass, B. M., Avolio, B. J., Jung, D. I., \&Berson, Y. (2003). Predicting unit performance by assessing transformational and transactional leadership. Journal of Applied Psychology, 88(2), 207-218.

3. Benn, S., Dunphy, D., \& Griffiths, A. (2014). Organizational change for corporate sustainability. Routledge

4. Bommer, W. H., Rich, G. A., \& Rubin, R. S. (2005). Changing attitudes about change: Longitudinal effects of transformational leader behavior on employee cynicism about organizational change. Journal of Organizational Behavior, 26(7), 733-753.

5. Burkhardt, M. E. (1994). Social interaction effects following a technological change: A longitudinal investigation. Academy of Management Journal, 37(4), 869-898.

6. Burkhardt, M. E. (1994). Social interaction effects following a technological change: A longitudinal investigation. Academy of Management Journal, 37(4), 869-898.

7. Cogliser, C. C., Schriesheim, C. A., Scandura, T. A., \& Gardner, W. L. (2009). Balance in leader and follower perceptions of leader-member exchange: Relationships with performance and work attitudes. The Leadership Quarterly, 20(3), 452465.

8. Conner, D. R. (1992). Managing at the speed of change: How resilient managers succeed and prosper where others fail. New York: Villard Books.

9. Cropanzano, R., \& Mitchell, M. S. (2005). Social exchange theory: An interdisciplinary review. Journal of Management, 31(6), 874-900.

10. Cummings, J. N., \& Higgins, M. C. (2006). Relational instability at the network core: Support dynamics in developmental networks. Social Networks, 28(1), 38-55.

11. Cummings, T., \& Worley, C. (2014). Organization development and change. Stamford, CT: Cengage Learning. 42(2), 81-91.

12. Cunningham, C. E., Woodward, C. A., Shannon, H. S., MacIntosh, J., Lendrum, B., Rosenbloom, D., \& Brown, J. (2002). Readiness for organizational change: A longitudinal study of workplace, psychological and behavioral correlates. Journal of Occupational and Organizational Psychology, 75(4), 377-392

13. Dulac, T., Coyle-Shapiro, J. A., Henderson, D. J., \& Wayne, S. J. (2008). Not all responses to breach are the same: The interconnection of social exchange and psychological contract processes in organizations. Academy of Management Journal, 51(6), 1079-1098.

14. Dutton, J. E., \&Ragins, B. R. (Eds.). (2007). Exploring positive relationships at work: Building a theoretical and research foundation. Mahwah, NJ: Lawrence Erlbaum Associates. 387-400.

15. Elias, S. M. (2009). Employee commitment in times of change: assessing the importance of attitudes toward organizational change. Journal of Management, 35(1), 37-55.

16. Ely, R. J., \& Thomas, D. A. (2001). Cultural diversity at work: The effects of diversity perspectives on work group processes and outcomes. Administrative Science Quarterly, 46(2), 229-273. 
17. Foks, M. (2015) Antecedents of commitment to change : a study about the contribution of change related variables, individual variables, communication variables and work-relationships to employees' commitment to organizational change.

18. Herscovitch, L., \& Meyer, J. P. (2002). Commitment to organizational change: Extension of a three-component model. Journal of Applied Psychology, 87(3), 474-487.

19. Higgins, M. C., \& Thomas, D. A. (2001). Constellations and careers: Toward understanding the effects of multiple developmental relationships. Journal of Organizational Behavior, 22(3), 223-247.

20. Hill, N. S., Seo, M. G., Kang, J. H., \& Taylor, M. S. (2012). Building employee commitment to change across organizational levels: The influence of hierarchical distance and direct managers' transformational leadership. Organization Science, 23(3), 758-777.

21. Hofmann, D. A., Morgeson, F. P., \&Gerras, S. J. (2003). Climate as a moderator of the relationship between leader-member exchange and content specific citizenship: safety climate as an exemplar. Journal of Applied Psychology, 88(1), 170-178.

22. Kram, K.E. and Higgins, M.A. (2009). A new mindset on mentoring: Creating developmental networks at work. Sloan Management Review, Cambridge, MA

23. Liden, R. C., Wayne, S. J., \&Sparrowe, R. T. (2000). An examination of the mediating role of psychological empowerment on the relations between the job, interpersonal relationships, and work outcomes. Journal of Applied Psychology, 85(3), 407-416.

24. Logan, M. S., \&Ganster, D. C. (2007). The effects of empowerment on attitudes and performance: The role of social support and empowerment beliefs. Journal of Management Studies, 44(8), 1523-1550.

25. Martin, R. \&Epitropaki, O. (2005). From ideal to real: A longitudinal study of the role of implicit leadership theories on leader-member exchanges and employee outcomes. Journal of Applied Psychology, 90(4), 659-676.

26. Meyer, J. P., \& Allen, N. J. (1991). A threecomponent conceptualization of organizational commitment. Human resource management review, $1(1), 61-89$.

27. Moran, J. W., \&Brightman, B. K. (2000). Leading organizational change. Journal of Workplace Learning, 12(2), 66-74.

28. Oreg, S. (2006). Personality, context, and resistance to organizational change. European Journal of Work and Organizational Psychology, 15(1), 73101.

29. Seers, A., Petty, M. M., \& Cashman, J. F. (1995). Team-member exchange under team and traditional management a naturally occurring quasiexperiment. Group \& Organization Management, 20(1), 18-38.

30. Shaw, S., Ashcroft, J., \&Petchey, R. (2006). Barriers and opportunities for developing sustainable relationships for health improvement: The case of public health and primary care in the UK. Critical Public Health, 16(1), 73-88.

31. Sherony, K. M., \& Green, S. G. (2002). Coworker exchange: relationships between coworkers, leadermember exchange, and work attitudes. Journal of Applied Psychology, 87(3), 542-548.

32. Thompson, J. D. (2011). Organizations in action: Social science bases of administrative theory. New Brunswick, N.J.: Transaction Publishers.

33. Uhl-Bien, M., Graen, G. B., \&Scandura, T. A. (2000). Implications of leader-member exchange (LMX) for strategic human resource management systems: Relationships as social capital for competitive advantage. Research in Personnel and Human Resources Management, 18, 137-186.

34. Van Dam, K., Oreg, S., \&Schyns, B. (2008). Daily work contexts and resistance to organizational change: The role of leader-member exchange, development climate, and change process characteristics. Applied Psychology, 57(2), 313334.

35. Woodward, C. A., Shannon, H. S., Cunningliam, C. E., McIntosh,J. E., Lendrum, B., Rosenbloom, D., \& Brown, J. (1999). The impact of re-engineering and other cost reduction strategies on the staff of a large teaching hospital: A longitudinal study. Medical Care, 7, 547-555. 